\title{
UTERINE CONTRACTILITY: FOCUS ON SOME NEW TARGETS TO AFFECT THE FUNCTION
}

\author{
Drozd O. O., Moroz O. F.
}

\section{INTRODUCTION}

Despite the hundreds years of experience, decades of tremendous discoveries and breakthroughs clinical gynecology and obstetrics still faces the problem of preterm labors and postpartum hemorrhages in a global scale $^{1}$. Also one the goal of sustainable development (SDG) for the nearest 10 years is to reduce the rate of maternal mortality ${ }^{2}$.

Through the years scientists were struggling to understand the mechanisms underlying uterine functioning and regulation and to date only a few white spots remained. Current concepts of the processes of uterine smooth muscle contraction that represents the crucial function of uterus as the organ of fetus maturation and deliveringwere not reviewed in several recent years except of lastly published by $\mathrm{M}$. Ilicic et al. $^{3}$ Some aspects about myometrium development, structure, function and regulation are outlined by researchers from our group ${ }^{4}$. Based of these findings several effective therapeutic approaches have been developed and introduced into clinic but still new avenues are supposed to explore to increase successive outcomes. As it is reported by S. Siricilla et al., several stages should be reached to find, develop, test and introduce into clinical practice 5 . In recent years molecular targets or end points of regulatory mechanisms are under the focus of researches and several

${ }^{1}$ Global, Regional, and National Estimates of Levels of Preterm Birth in 2014: A Systematic Review and Modelling Analysis / Chawanpaiboon S. et al. The Lancet. Global Health. 2019. Vol.7, № (1) P. 37-46. URL: https://doi.org/10.1016/S2214109X(18)30451-0.

2 Maternal mortality : веб сайт. URL: https://www.who.int/news-room/factsheets/detail/maternal-mortality.

3 Ilicic M., Tamas Z., Paul J.W.The Regulation of Uterine Function During Parturition: An Update and Recent Advances. Reproductive Science. 2020. Vol. 27. № (1). P. 3-28. URL: https://doi.org/10.1007/s43032-019-00001-y.

${ }^{4}$ Moroz O., Zholos A. Uterine myocytes: development, structure and function. Advances in Medicine and Biology. Editor L.V. Berhardt, Nova Science Publishers, Inc. 2019.Vol. 148. P. 27-96.

5 Siricilla S., Chisom C.I Herington J.L. Drug Discovery Strategies for the Identification of Novel Regulators of Uterine Contractility. Current Opinion in Physiology. 2019. Vol. 13. P. 71-87. URL: https://doi.org/10.1016/j.cophys.2019.10.012 
perspective substances are investigated for their clinical benefit. So in this article we are going to describe current theory of myometrium function in pregnancy and to describe our findings concerning the role of particular ion channels as the potential molecular target for normalization of the uterine contractility.

\section{Consepts of myometrium function in pregnancy and labor}

The main trend of modern obstetrics is the most careful management of pregnancy and its final stage - the labor. It is known that the features of the course of labor largely determine the perinatal outcomes for the mother and the newborn. According to the World Health Organization (WHO), every day about 800 women and almost 8,000 newborns die from complications that occurred during pregnancy, labor and the immediate postpartum period. Therefore, the pathology of the contractile activity of human uterus is one of the urgent problems in modern obstetrics. Impairment of uterine contractile activity is the basis of most obstetric problems: both preterm pregnancy and delay pregnancy, abnormalities in labor, hypotonic uterine bleeding, maternal and child injuries, septic postpartum diseases and generally worsen maternal and perinatal morbidity and mortality. In 184 countries around the world, the preterm labor rate ranges from 5 to $18 \%$. In Ukraine, the preterm labor rate is 4.6-8.9\%, but the cost of treating preterm infants exceeds $50 \%$ of the total budget allocated for neonatal care ${ }^{6}$. Complications of preterm labor are the main factors of death among children under 5 years old and accounted for about 1 million deaths in $2015.75 \%$ of these deaths can be prevented through ongoing and cost-effective interventions, including research.

To date, abnormal contractile activity of the uterus is one of the frequent complications of the gestational process and is observed in $11-42 \%$ of labor ${ }^{7,8}$. So, every year in Ukraine there are about 20,000 cases of pathological labor in women. In 2014, the number of labor with thelabor abnormality was 16952 cases, or 38.3 per 1000 labor $^{9}$. Violations of the

\footnotetext{
${ }^{6}$ Нові клінічні настанови 3 акушерства та гінекології: затв. рішенням Загальних Зборів Членів Громадської організації Київського Міського відділення асоціаціцї акушерів-гінекологів України від 21 грудня 2017 р. № 21/12. / Профессиональные издания, 2019. $266 \mathrm{c.}$

${ }^{7}$ Продолжительность “нормальных” родов в современных условиях. / Баев О.Р. и др. Акушерство и гинекология. 2012. № 1. С. 49-54.

8 Авраменко Т.В., Мощич А.П. Оценка эффективности и безопасности применения препарата Вибуркол для подготовки шейки матки к родам и профилактики аномалий родовой деятельности. Здоровье женщины. 2016. № 7(113). C. 73-78.

${ }_{9}$ Сучасні підходи до преіндукції та індукції пологів, засновані на доказах / Вдовиченко Ю.П. та ін. Здоровье женщинны. 2016. № 3. С. 24-29.
} 
laborprocess take third place in the structure of indications for cesarean section and are one of the causes of perinatal and maternal complications $^{10,11}$.

Many publications address issues related to both obstetric tactics in violation of contractile activity of the uterus and warnings of the development of labor abnormalities. Nevertheless, the frequency of them over the past decades has not tended to decrease, and the problems associated with this pathology remain relevant ${ }^{12}$.

Violation of the contractile activity of the uterus is also the most common factor in postpartum uterine bleeding. Currently, $1.2 \%$ of labors are complicated by postpartum hemorrhage, which leads to maternal mortality of $3 \%$. Worldwide, it is observed 8.7 million times and leads to death from 44,000 to 86,000 women per year, making postpartum hemorrhage the main cause of death. About 0.4 women per 100,000 labors die from hypotonic bleeding in the UK, and around 150 women die per 100,000 labors in Africa ${ }^{13}$.

There is no doubt that in order to develop the most effective methods for the prevention and treatment of abnormalities of uterine contractility during pregnancy, labor and the early postpartum period, fundamental knowledge is needed on the mechanism of myometrial contraction at the cellular and molecular levels.

With a full-term pregnancy, on the eve of an urgent labor, changes occur in the entire mother-pregnant uterus-placenta-fetus system. The morphological, physiological, biochemical and biophysical nature of these changes is to provide contractile activity of the uterus and to expel the fetus. In the preparation of a woman's body for labor, a certain place belongs to the central nervous system. By the end of pregnancy and the onset of labor, a woman has a predomination of inhibition processes in the cerebral cortex and the increase in excitability of subcortical structures - the hypothalamic-pituitary system,

\footnotetext{
${ }^{10}$ Нові клінічні настанови з акушерства та гінекології: затв. рішенням Загальних Зборів Членів Громадської організації Київського Міського відділення асоціаціцї акушерів-гінекологів України від 21 грудня 2017 р. № 21/12. / Профессиональные издания, 2019. 266 с.

11 Влияние продолжительности родового акта на перинатальные исходы / Железова М.Е. и др. Практическая медицина. 2017. № 7(108) Акушерство. Гинекология. С. 12-17.

${ }^{12}$ Use of Mifepristone to Ripen the Cervix and Induce Labor in Term Pregnancies. I BerkaneN. et al. American Journal of Obstetrics and Gynecology.2005. Vol. 192. № (1). P. 114-20. URL: https://doi.org/10.1016/j.ajog.2004.05.084.

${ }^{13}$ SebghatiM., Chandraharan E. An Update on the Risk Factors for and Management of Obstetric Haemorrhage. Women's Health. 2017. Vol. 13. № (2). P. 34-40. URL: https://doi.org/10.1177/1745505717716860.
} 
amygdala nuclei of the limbic system and the spinal $\operatorname{cord}^{14}$. By the end of pregnancy, structural and functional changes occur in the uterus. In myocytes, mitosis is observed, which confirms the presence of hyperplasia: by the end of pregnancy, each muscle fiber of the uterus increases 10-11 times, reaching 400-500 microns. Muscle bundles hypertrophy due to the accumulation of protoplasm mass and its swelling. They are homogenized, become hydrophilic, lose their contour. At the same time as hyperplasia and hypertrophy of muscle and connective tissue elements, structural changes occur in the blood and lymph vessels of the uterus - the network of capillaries and precapillaries increases, their location between the muscle elements changes, the reception zone increases ${ }^{15}$.

Regulation of uterine contractions by autonomic nervous system is carried out by mediators, the main of which are acetylcholine, adrenaline and norepinephrine. With the physiological progress of pregnancy, the tone of the adrenergic system prevails. Catecholamines (adrenaline, norepinephrine) mediate adrenergic effects on the myometrium, interacting with adrenergic receptors of smooth muscle cells ${ }^{16}$. Adrenaline stimulates the contractile activity of the non-pregnant uterus and inhibits spontaneous labor, while norepinephrine causes contractions of the pregnant uterus. Therefore, during pregnancy, only a small amount of norepinephrine is found in the uterus. For data obtained by Abramchenko V.V., a decrease in the amount of adrenaline and an increase in the content of norepinephrine in the uterus is one of the mechanisms that induce the onset of labor ${ }^{17}$. With weak labor a decrease in the concentration of catecholamines is detected mainly due to norepinephrine. During contractions the uterus experiences a pronounced effect from the cholinergic system. Acetylcholine has a stimulating effect on the muscles of the uterus. Before labor and labor, a high level of acetylcholine with a low activity of acetylcholinesterase is observed in the blood plasma of pregnant women. In labor, under the influence of a certain amount of acetylcholine, uterine muscle contractions occur, the destruction

${ }^{14}$ Factors Implicated in the Initiation of Human Parturition in Term and Preterm Labor: A Review/ Ravanos K. et al. Gynecological Endocrinology. 2015. Vol. 31 № (9). P. 679-683. URL: https://doi.org/10.3109/09513590.2015.1076783.

${ }^{15}$ Myometrial Mechanoadaptation during Pregnancy: Implications for Smooth Muscle Plasticity and Remodelling /Wu X. et al. Journal of Cellular and Molecular Medicine. 2008. Vol. 12. № (4) P. 1360-1373. URL: https://doi.org/10.1111/j.15824934.2008.00306.x.

${ }^{16}$ Remodeling of Uterine Innervation / Latini C. et al.Cell and Tissue Research.2008. Vol. 334. № (1) P. 1-6. URL: https://doi.org/10.1007/s00441-008-0657-х.

17 Абрамченко, В.В. Концепция энергетического дефицита и нарушенной функции митохондрий в патогенезе аномалий родовой деятельности. Проблемь репродукции . 2001. № 4. С. 39-43. 
of acetylcholine by cholinesterase is accompanied by a gradual decrease in the contraction wave. The following uterine contractions occur when a new portion of acetylcholine appears. The effect of acetylcholine and norepinephrine on the uterus is summarized ${ }^{18}$. With the onset of pregnancy, cholinergic innervation of the uterus is suppressed ${ }^{19}$.

With the development of pregnancy, the excitability of $\beta$-receptors of adrenergic nerves, which inhibit the action of adrenergic compounds, significantly increases. It is believed that progesterone is the main compound that modifies the function of $\beta$ receptors. A decrease in progesterone levels by the time of labor reduces the inhibitory effect of adrenergic nerves and enhances the function of $\beta$ receptors responsible for the processes of excitation of cellular structures. In these processes, the leading role belongs to estrogens, which stimulate the accumulation of catecholamines ${ }^{20}$. An adrenergic nerve suitable for the uterus can create a spinal reflex arc, as a result of which the expansion of the cervix stimulates the contraction of the uterus. There is reason to believe that adrenergic innervation increases the sensitivity of the myometrium to oxytocin, serotonin, and possibly prostaglandin $\mathrm{F} 2 \alpha$, and also affects the blood flow in the uterine vessels, a decrease in which stimulates the onset of labor. However, it should be noted that the denervated uterus in animals functions relatively well in labor, and spinal paralysis of all levels does not affect the course of labor in humans.

Over the past decades, the contraction of the uterus and the opening of the cervix during labor have been considered primarily from the standpoint of contraction-retraction-distraction, "hydraulic wedge" and "triple downward gradient". The last hypothesis suggests that the wave of excitation from the pacemaker, which is located in the right corner of the uterus, goes to the left corner of the uterus, body and lower segment. At the same time, the physiological denervation of the uterus during pregnancy was proven, but many obstetricians continue to use this theory until now, although the pacemaker as a morphological unit has not been detected ${ }^{21}$.

18 Савицкий Г.А., Савицкий А.Г. Родовая схватка человека: клиникобиомеханические аспекты. Сю-Петербугр : “ЭЛБИ-СПБ”, 2010. 240 с.

19 Effect of Estrogen on Muscarinic Acetylcholine Receptor Expression in Rat Myometrium / AbdallaF. et al. Molecular and Cellular Endocrinology. 2004. Vol. 213. № 2. P. 139-48. URL: https://doi.org/10.1016/j.mce.2003.10.040.

20 Tocolytic Therapy with Fenoterol Induces Selective Down-Regulation of $\beta$-Adrenergic Receptors in Human Myometrium /EngelhardtS. et al. The Journal of Clinical Endocrinology \& Metabolism. 1997. Vol. 82. № 4. P. 1235-42. URL: https://doi.org/10.1210/jcem.82.4.3885.

${ }^{21}$ Young R.C., Goloma G. Mechanotransduction in Rat Myometrium: Coordination of Contractions of Electrically and Chemically Isolated Tissues. Reproductive Sciences.2011. Vol.18. № (1). P. 64-69. URL: https://doi.org/10.1177/1933719110379637. 
Currently, there is an opinion that the contraction of all parts of the uterus occurs synchronously due to the instantaneous spread of excitation through gap junctions (nexuses), which are a special mechanism for conducting excitation, coordinates the activity of the entire pool of muscle cells of the myometrium, and the number of nexuses increases in direct proportion to gestational age. These contacts consist of holes (channels formed by six connexin proteins, connected symmetrically to six conexins of the adjacent myocyte), which connect the internal environment of the cells.In myometrium, the 43-Sha protein, called connexin 43, is the main component of gap $\operatorname{contact}^{22}$. A number of researchers associate the synchronization of contraction of all parts of the uterus with the neurogenic activity of myocytes, believing that although the latter are connected by nexuses, many of them form direct synaptic contacts with axons, which innervates them. It is likely that these particular myocytes are pacemaker cells ${ }^{23}$.

The normal course of labor depends on the state of biochemical processes in the muscle fibrils of the contracting uterus. The muscle cell contains the so-called contractile proteins. Myofibrillar proteins involved in the contractile function of muscle fibers include actin, myosin, actomyosin (a complex compound of two protein components) and tropomyosin. Contractile proteins have enzymatic activity with respect to a complex organic compound - adenosine triphosphoric acid (ATP), causing its decomposition, accompanied by the release of a large amount of energy ${ }^{24}$. The released chemical energy, without passing into heat, is directly transformed into mechanical energy - contraction (reduction in size). The activity of this reaction, and, consequently, the power of contraction, depends on the content of these components in the cell and on the ionic composition of the medium (calcium, potassium, cobalt, etc.). The content of contractile proteins in the uterine muscle in its different departments may differ. The upper part of the uterus is richest in them. In the development of labor, the effect of serotonin and catecholamines was established. They are fixed in myocytes, provide an increasing intensity of metabolic processes

${ }^{22}$ Alterations in Gap Junction connexin43/connexin45 Ratio Mediate a Transition from Quiescence to Excitation in a Mathematical Model of the Myometrium / Sheldon R.E. et al. Journal of the Royal Society. 2014. Vol. 11. № (101). URL: https://doi.org/: 10.1098/rsif.2014.0726.

23 Роль биологически активных молекул в развитии сократительной деятельности матки / Кузьминых Т.У. и др. Журнал акушерства и женских болезней. 2019. Т. 68. № 1. С. 21-27.

24 Абрамченко, В.В. Концепция энергетического дефицита и нарушенной функции митохондрий в патогенезе аномалий родовой деятельности. Проблемь репродукиии. 2001. № 4. С. 39-43. 
and increase the contractile properties of proteins ${ }^{25}$. Serotonin, catecholamines together with estrogens alters the ratio of adrenergic components that enhance the function of $\alpha$-receptors of the nervous structures and promote the release of progesterone, which reduces the excitability, contraction and tension of the myometrium. Part of myocytes, apparently, is completely released from progesterone effect to their level of resting excitability and contractility. As a result, in the myometrium foci of contraction appear but they do not increase intrauterine pressure and do not inhibit cervical function ${ }^{26}$.

There is a lot of data in the literature on the role of oxytocin in uterine contraction, but so far deep details how this hormone ineract with other regularoty substances in myocytes has not been completely clarified. Its effect on the uterus is directly dependent on the content of sex hormones: estrogens increase the sensitivity of the myometrium to it, and progesterone depresses. Some researchers indicated the dependence of myometrial contractions on the activity of blood oxytocinase, but another studings have not confirmed that oxytocinase activity changes significantly before, during, and after labor ${ }^{27}$. Apparently, blood oxytocinase does not play a significant role in the regulation of oxytocin level in the development of labor. Oxytocin has a specific effect on enhancing the contractile activity of the uterus, but so far there is no convincing evidence that this compound is responsible for the onset of labor ${ }^{28}$. Prostaglandin F2 $\alpha$ is a highly specific compound that causes increased contraction of the myometrium and stimulates the release of oxytocin from the posterior pituitary gland ${ }^{29}$. This indicates a synergy of their action. Probably, oxytocin and prostaglandin complement each other in action on the cytoplasmic membrane, changing the ionic equilibrium between its outer and inner surfaces to optimal values of the outputs of the action potentials.

${ }^{25}$ Taggart M. J, Morgan K.G. Regulation of the Uterine Contractile Apparatus and Cytoskeleton. Seminars in Cell \& Developmental Biology. 2007. Vol. 18. № (3). P. 296-304. URL: https://doi.org/10.1016/j.semcdb.2007.05.006.

26 Molecular Evidence of Functional Progesterone Withdrawal in Human Myometrium / Nadeem L. et al. Nature Communications. 2016. Vol. 7. № (1). P. 115-165. URL: https://doi.org/10.1038/ncomms11565.

${ }^{27}$ Klimek M. Comparative Analysis of ACTH and Oxytocinase Plasma Concentration during Pregnancy. Neuroendocrinology Letters. 2005. Vol. 26. № (4). P. 337-341. URL: www.nel.edu.

28 Arrowsmith S., Wray S. Oxytocin: Its Mechanism of Action and Receptor Signalling in the Myometrium. Journal of Neuroendocrinology. 2014. Vol. 26. № (6). P. 356-69. URL: https://doi.org/10.1111/jne.12154.

29 Айламазян Э.К., Абрамченко В.В. Простагландины в акушерскогинекологической практике. Санкт-Петербург : Петрополис, 1992. 27 с. 
Sex hormones produced during pregnancy mainly by the fetoplacental complex, estrogens and progesterone, are key in ensuring physiological, morphological, biophysical and biochemical processes, both during pregnancy and during the development of labor. With the progress of pregnancy the circulation of estrogen in the blood increases reaching a maximum during labor. The most important estrogen in pregnancy in humans is estriol. Its synthesis occurs in the placenta with the direct participation of the fetus. Estrogens determine the complex of biophysical changes in the cells of the myometrium, creating their ability to contract. They increase the excitability of the targeted structures of the myometrium to the action of oxytocin, prostaglandin, serotonin and catecholamines. Estrogens directly or indirectly excite the neurohypophysis and increase the release of oxytocin. Estrogens also contribute to the release of progesterone from binding sites on uterine receptor proteins, and this effect can be direct or indirect through humoral or neurohumoral systems. The accumulation and release of active forms of serotonin, catecholamines and prostaglandin depend on the content of estrogen ${ }^{30}$. Progesterone is an important hormone for maintaining pregnancy. One of the biophysical properties of progesterone in humans and animals is the hyperpolarization of myometrial cells (up to $65 \mathrm{mV}$ ), as a result of which their excitability, mechanical activity, and intraorgan coordination are reduced. However, women did not show a significant decrease in plasma progesterone before labor, although there was a significant decrease in progesterone after the labor of the placenta. It has been suggested that progesterone is released from the uterine tissue by the time of labor, and its circulation in the blood, despite increased excretion of pregnanediol, remains stable for some time ${ }^{31}$.

In the development and progress of labor, mechanical factors of uterine arousal are of some importance. An increase in the volume of the uterus to some optimal values (polyhydramnios, multiple pregnancies, extraamnial injection of solutions) causes labor activity. The stretching of the smooth muscle strip in vitro significantly increases the action potential and mechanical activity of muscle cells, although the mechanism of this phenomenon is not well understood. If the stretching of muscle tissue exceeds certain limits (over $30 \%$ of the initial state), then the mechanical

30 Estrogen Receptor (ER) Expression and Function in the Pregnant Human Myometrium: Estradiol via ER $\alpha$ Activates ERK1/2 Signaling in Term Myometrium / Welsh T. et al. Journal of Endocrinology. 2012. Vol. 212. № (2). P. 227-38. URL: https://doi.org/10.1530/JOE-11-0358.

${ }^{31}$ Mesiano S. Myometrial Progesterone Responsiveness and the Control of Human Parturition. Journal of the Society for Gynecologic Investigation. 2004. Vol. 11. № (4). P. 193-202. URL: https://doi.org/10.1016/j.jsgi.2003.12.004. 
activity and excitability of muscle cells decreases sharply, and then completely stops ${ }^{32}$. Generic activity is intensified not only by an increase in stretching to certain limits, but also by a decrease in volume, for example, with the outflow of amniotic fluid. Based on such kind of suggestion, the method of labor stimulation and intensification of contractions by opening the fetal bladder ${ }^{33}$ and in recent decades significant background of molecular mechanisms of this effect has been obtained.

The role of the fetal pituitary gland and the hypothalamus in duration of pregnancy and development of labor is not fully understood. As experimental studies have shown, the destruction of the pituitary or hypothalamus of animals leads to an increase in the duration of pregnancy. Stimulation of the adrenal cortex of the fetus ACTH, as well as the introduction of cortisone or synthetic dexamethasone leads to premature labor $^{34}$. However, when the fetus was removed, leaving the placenta in rats, mice, and monkeys, there was no prolongation of its labor ${ }^{35}$. The death of the fetus in late pregnancy in women, as a rule, does not cause inhibition of labor, laborinitiates at term. These data indicate the absence of a significant role of ACTH and the adrenal glands of the fetus in the onset of labor.

A reduction in the frequency of preterm labor is facilitated by a set of measures, among which preference is given to medications. In clinical practiceworldwide, tocolytic drugs of various mechanisms of action have been used for more than 40 years, but the frequency of preterm labor does not change.The effect of drugs on the uterus can be either direct or indirect. Currently, certain successes have been achieved in the treatment of preterm labor by drugs that suppress the contractile activity of the uterus. Among them: $\mathrm{Mg}^{2+}$ cations in the form of a $25 \%$ solution of magnesium sulfate, $\beta$-adrenergic agonists (terbutaline, alupent, ritodrin, partusisten, hexoprenaline), phosphodiesterase blockers (papaverine), L- type $\mathrm{Ca}^{2+}$ channelsantagonists (nifedipine), oxytocin receptor blockers (atosiban) nitric oxide donors (nitroglycerin) and prostaglandin synthesis inhibitors (indomethacin). At the

${ }^{32}$ Retosiban Prevents Stretch-Induced Human Myometrial Contractility and Delays Labor in Cynomolgus Monkeys / Aye I. et al. The Journal of Clinical Endocrinology and Metabolism. 2018. Vol. 103/ № (3). P. 1056-1067. URL: https://doi.org/10.1210/jc.201702195.

33 Бакшеев Н.С., Орлов Р.С. Сократительная функция матки. Киев : Здоровья, 1986. 184 c.

34 Арутюнян, Т.Г., Линде В.А., Эльжорукаева Ж.А. Роль кортикотропинрилизинг гормона в инициации родов. Медицинский вестник юга России. Ростовна-Дону. 2013. № 4. С. 26-29.

35 Caldeyro-Barcia R, Alvarez H., Reynolds S. A letter understanding of uterial contractility though simultations recording with internal and seven channel external method. Surg. Obstet. Gynaec. 1950. V. 91. № 3. P. 641-652. 
same time, the presence of a large number of drugs used to stop preterm labor indicates their insufficient effectiveness ${ }^{36}$.

Experimental studies were conducted comparing the relaxing effect of magnesium sulfate, ginipral and nifedipine on the contractile activity of smooth muscle cells of the myometrium of pregnant women and a comparative analysis of the effectiveness of these tocolytic drugs in the treatment of preterm labor. The results showed that the calcium channel blocker nifedipine is a highly effective drug that is devoid of a number of side effects and negative effects on the fetus ${ }^{37}$.

Now in Ukraine, as also in a world obstetric practice, hexoprenaline, nifedipine, an antagonist of oxytocin receptors and indomethacin are used whentocolysis is needed ${ }^{38}$. However, a significant decrease in the frequency of preterm labor is not observed and many research groups are working to find other perspectives to attenuate preterm uterine contractility.

To date, synthetic oxytocin (an analogue of the natural polypeptide) is used to correct insufficient uterine contractions during labor around the world. And to increase the contractile activity and tone of the myometrium in the postpartum period, in addition to oxytocin, a long-acting oxytocin agonist - carbetocin is used ${ }^{39}$ and alsomedications containing ergometrine and prostaglandins ${ }^{40,41}$.

One of the first references in the available literature with the descritption of an attempt how to regulate the contractile activity of the myometrium dates back to 1906, when Dale N.N. published the results of experimental data on animals, including primates, about the effect of the pituitary gland extract on the uterus ${ }^{42}$. The author in all cases noted tonoicomotor effect. Apparently, the studies were

36 Дрозд О.О., Орчаков В.О. Сучасний погляд на токолітичну терапію при передчасних пологах. Збірник наукових працьь асочіащіі акушерів-гінекологів України. 2015. Вип. 2(36). С. 64-68.

37 Дрозд О.О. Порівняльна оцінка ефективності різних методів токолітичної терапії при передчасних пологах : автореф. дис. на здобуття наук. ступеня канд. мед. наук : 14.01.01. Київ, 2006. 20 с.

${ }^{38}$ Нові клінічні настанови 3 акушерства та гінекології: затв. рішенням Загальних Зборів Членів Громадської організації Київського Міського відділення асоціаціцї акушерів-гінекологів України від 21 грудня 2017 р. № 21/12. Профессиональные издания. 2019. $266 \mathrm{c.}$

39 Postpartum uterine response to oxytocin and carbetocin / Amsalem H.et al. J Reprod Med. 2014. Vol. 59. № 3-4. P. 167-173.

${ }^{40}$ Prophylactic use of ergot alkaloids in the third stage of labour / Liabsuetrakul T. et al. Cochrane Database Syst Rev. 2007. Issue 2:Art No:CD005456.

${ }^{41}$ Prostaglandins for prevention of Postpartum haemorrhage / Gulmezoglu A.M. et al.Cochrane Database Syst Rev. 2004. Issue I:Art. N: CD000494.

${ }^{42}$ Dale H.H. On some physiological actions of ergot. J. Physiol. 1906. Vol. 34. № (3). P. 163-206. 
carried out so actively that already in 1909 the pituitary gland extract began to be used in practical medicine. W. Blair Bell in J. Physiology described the clinical use of pituitary gland extract in labor and the early postpartum period with hypotonic bleeding. The effect noted in practice was stronger than the effect of the use of ergot alkoloid (ergot) ${ }^{43}$. A new stage in the study of the possibility of regulating the contraction of smooth muscle cells of the myometrium began after the synthesis of oxytocin. In 1953, an American scientist Vincent Du Vigno, together with his colleagues, found out the structure of oxytocin, a cyclic polypeptide. Among the known natural compounds, such cyclic structures have not previously been encountered. The following year, the scientist first synthesized this substance. This was the first case of in vitro synthesis of a polypeptide hormone ${ }^{44}$.

Of interest is the statement of authoritative authors on the study of the action of oxytocin that, besides being known for the uterostimulating effect of oxytocin, the exact mechanism of how this stimulation is carried out is, surprisingly, still definitive indefined ${ }^{45}$.

Since the synthesis of oxytocin and despite its widespread use in obstetric practice around the world, many questions of the regulation of contractile activity of the human myometrium during pregnancy, labor and the postpartum period remain open ${ }^{46}$.

\section{Ion channels as molecular target to regulate contractility}

Excitation and contraction of uterine myocytes as any other excitable cells originate on plasma membrane where ion currents flow through several types of channels. As S.Wray et al. describes, voltage-sensitive calcium channels, non-selective cation channel, potassium and chlorides ones as well as channels gated by ligands via G-protein coupled receptors (GPCR) are involved in generation of contractions and signal propagation ${ }^{47}$. Functional

43 Blair Bell W.The pituitary body and the therapeutic value of the infundibular extract in shock, uterine atony, and intestinal paresis. Br J Med. 1909. Vol. 2(2553). P. 1609-1613. URL: https://doi.org/10.1136/bmj.2.2553.1609.

${ }^{44}$ Du Vigneaud V., Resller S., Trippett S. The sequence of amino acids in oxytocin, with a proposal for the structure of oxytocin J. Biol. Chem. 1953. Vol. 205(2). P. 949-957.

45 Arrowsmith S, Wray S. Oxytocin: Its Mechanism of Action and Receptor Signalling in the Myometrium. Journal of Neuroendocrinology.2014. Vol. 26. № (6). P. 356-69. URL: https://doi.org/10.1111/jne.12154.

${ }^{46}$ Which uterotonic is better to prevent the postpartum hemorrhage? Latest news in terms of clinical efficacy, side effects, and contraindications: a systematic review / Gizzo S. Reprod Sci. 2013. Vol. 20. № 9. P. 1011-1019. URL: https://doi.org/10.1177/ 1933719112468951.

47 Progress in Understanding Electro-Mechanical Signalling in the Myometrium /

Wray S. et al.Acta Physiologica 2015.Vol. 213. № (2). P. 417-31. URL: ttps://doi.org/10.1111/apha.12431. 
activity of all these channels often is regulated by hormones and local factors acting in myometrium at the stages of expression, post-translational modifications, membrane trafficking/ incorporation / internalization or sensitivity changes ${ }^{48}$. Within this section we are going to focus on some types of ion channels that become a targets for investigation as potent tools to affect uterine contractility.

GPCR could have various effectors in signaling pathways and often these are ion channels. In this case hormones or neurotransmitters that bind to specific GPCR may change channel functional state directly binding physically G-protein subunits and channel protein or with the help of second messengers and protein kinases ${ }^{49}$.

In uterine smooth muscle cells GPCR are represented by oxytocin receptors, prostaglandin E2 and F2 receptors both for humans and rodents that are mostly used as animal models to study myometrium contractility ${ }^{50}$ and muscarinic receptors of type 2 and 3 that are involved in regulation of contractility in rodents only but found expressed in human myometrium too $^{51}$. Muscarinic receptors mediate downstream signaling that leads to stimulation of contractions via IP3 dependent release of stored calcium and increasing ofcontractile filaments calcium sensitivity provided by protein kinase $\mathrm{C}^{52}$. Expression of these receptors may be increased by estrogens but their role in human gestation and laboring is not clarified ${ }^{53}$.

${ }^{48}$ Sanborn B. M. Hormonal Signaling and Signal Pathway Crosstalk in the Control of Myometrial Calcium Dynamics Seminars in Cell and Developmental Biology. 2007. Vol. 18. № 3. P. 305-331. URL: https://doi.org/10.1016/j.semcdb.2007.05.007.

49 Dascal N.Ion-Channel Regulation by G Proteins.Trends in Endocrinology and Metabolism.2001. Vol. 12. № 9. P. 391-398. URL: https://doi.org/10.1016/S10432760(01)00475-1.

${ }^{50}$ Central Role for Protein Kinase $\mathrm{C}$ in Oxytocin and Epidermal Growth Factor Stimulated Cyclooxygenase 2 Expression in Human Myometrial Cells / Wouters E. et al. BMC Research Notes. 2014. Vol. 7. № (1). P. 357. URL: https://doi.org/10.1186/17560500-7-357.

${ }^{51}$ Muscarinic Receptor Subtypes Involved in Carbachol-Induced Contraction of Mouse Uterine Smooth Muscle / Kitazawa T. et al. Naunyn-Schmiedeberg's Archives of Pharmacology. 200. Vol. 377. № (4-6). P. 503-513. URL: https://doi.org/ 10.1007/s00210-007-0223-1.

52 Effect of Estrogen on Muscarinic Acetylcholine Receptor Expression in Rat Myometrium / AbdallaF. et al. Molecular and Cellular Endocrinology. 2004. Vol. 213. № (2). P. 139-148. URL: https://doi.org/10.1016/j.mce.2003.10.040.

${ }_{53}$ Brauer M. M., Smith P.G. Estrogen and Female Reproductive Tract Innervation: Cellular and Molecular Mechanisms of Autonomic Neuroplasticity. Autonomic Neuroscience. 2015. Vol. 187. P. 1-17. URL: https://doi.org/10.1016/j.autneu. 2014.11.009. 
Prostaglandins act as paracrine regulators that are known to play a major role in initialization of parturition by not only via direct effect on contractile apparatus but also by enhancing the level of cytokines promote transomation of myocyts to their contractile phenotype ${ }^{54}$. The direct effect of prostaglandin $\mathrm{F}_{2 \alpha}$ underlies in signal transmission from its $\mathrm{G}_{\mathrm{q}}$ protein coupled receptor by IP3 that activates calcium release from sarcoplasmic reticlulum together with PKC-meidated phosphorylation of intracellular proteins and ion channels ${ }^{55}$.

Intracellular pathways mediated by G-protein coupled receptors regulation of myocytes contractility could involve transient receptor potential C (TRPC) channels that are found to serve as receptor-operated channels for extracellular calcium entry and are described with more detail in subsequent sections.

Classic uterotonic that is used in clinic - oxytocin - also act via GPCR. These receptors when being activated, not only provoke IP3 mediated release of calcium from intracellular stores but also were shown to suppress functional activity of $\mathrm{Na}^{+}$-activated potassium channel, Slo2.1, and this way facilitate depolarization of myocyte membrane that turns into calcium entry and contraction ${ }^{56}$. On the other hand oxytocin-induced calcium inflow could have another mechanism. As Schnitzler M. et al. report, TRPC ion channels may be involved in this effect because they are found to be DAG sensitive thus could supply calcium entry in response to hormones acting via $\mathrm{GPCR}^{57}$.

One more example of GP gated channels is NO-mediated regulation of uterine contractility where end targets are calcium activated potassium channels of large and small conductance and $\mathrm{Ca}_{\mathrm{v} 1}$ calcium channels. Protein kinase $\mathrm{G}$ provoke tocolysis by activating potassium outflow and attenuating calcium inflow ${ }^{58}$.

${ }^{54}$ Sivarajasingam S. P., Imami N., Johnson M.R. Myometrial Cytokines and Their Role in the Onset of Labour. The Journal of Endocrinology. 2016. Vol. 231. № (3). P. 101-119. URL: https://doi.org/10.1530/JOE-16-0157.

55 Myatt L., LyeS. J. Expression, Localization and Function of Prostaglandin Receptors in Myometrium. Prostaglandins Leukotrienes and Essential Fatty Acids. 2004. Vol. 70. № (2). P. 137-48. URL: https://doi.org/10.1016/j.plefa.2003.04.004.

${ }^{56}$ Oxytocin Can Regulate Myometrial Smooth Muscle Excitability by Inhibiting the $\mathrm{Na}+$-activated K + Channel, Slo2.1 / FerreiraJ. J. et al. The Journal of Physiology. 2019. Vol. 597. № (1). P. 137-49. URL: https://doi.org/10.1113/JP276806.

57 Mederos y Schnitzler M., Gudermann T., Storch U. Emerging Roles of Diacylglycerol-Sensitive TRPC4/5 Channels. Cells. 2018. Vol. 7. № (11). P. 218. URL: https://doi.org/10.3390/cells7110218.

${ }^{58}$ Essential Oil from Lippia Microphylla Cham.Modulates Nitric Oxide Pathway and Calcium Influx to Exert a Tocolytic Effect in Rat Uterus / Silva M. et al. Natural Product Research. 2019. Vol. Jun 5. P. 1-6. URL: https://doi.org/10.1080/14786419.2019. 1614578. 
Among GP gated channels are also those that are localized on cellular organelles. IP3 receptors of ER open their calcium permeable pore in response to hormones, oxytocin in particular ${ }^{59}$.

GP gated channels may receive income signals from $\mathrm{G}_{\mathrm{i} / \mathrm{o}}$ coupled receptors like M2 muscarinic receptors with the participationPLC $\delta$ and this pathway act coincidentally with more described $\mathrm{G}_{\mathrm{q} / 11}$ one ${ }^{60}$. G protein gated channels are also found to be regulated by regulator of G-protein signaling protein (RGS) that activate GTPase activity of $\mathrm{G} \alpha$ subunits and proteins that contain Gai/o-Loco (GoLoco) motif and act as guanine-nucleotidedissociation inhibitors of $\mathrm{G} \alpha$ subunits $^{61}$. Phospholipase $\mathrm{C}$ that is activated by GPCR also hydrolise PIP2 that suppress functioning of TRPC ion channels thus facilitating calcium entry through these cationic channels and contraction $^{62}$. PKC was also shown to affect the TRPV4 channel activity by its phosphorylation. This phenomenon is referred to as channel sensitivity and was described in experiments with both direct PKC and PKA activators and GPCR agonists and appeared to depend on a scaffolding proteins ${ }^{63}$. So, GP gates several types of ion channels in myometrium and could serve as molecular targets for pharmacological correction of uterine contractility in those cases when GPCR itself are poorly expressed or impaired.

Transient receptor potential channels remain in the focus of scientists during last decades especially after their first genes were sequenced ${ }^{64}$. These channels are cation nonselective, that are expressed in various types of excitable cells and demonstrate tempterature, stretch and $\mathrm{pH}$ sensitivity but

${ }^{59}$ Parkington H.C., Siriwardhana E.R., Coleman H.A. Intracellular Organelles; Key Regulators of Myometrial Activity. Current Opinion in Physiology. 2020. Vol. 13. P. 55-61. URL: https://doi.org/10.1016/j.cophys.2019.10.007.

${ }^{60}$ Critical Roles of Gi/o Proteins and Phospholipase C- $\Delta 1$ in the Activation of Receptor-Operated TRPC4 Channels / Thakur D.P. et al.Proceedings of the National Academy of Sciences of the United States of America. 2016. Vol. 113. № (4). P. 109-1097. URL: https://doi.org/10.1073/pnas.1522294113.

${ }^{61}$ Regulator of G-Protein Signalling and GoLoco Proteins Suppress TRPC4 Channel Function via Acting at Gai/O / Jeon J.P. et al. Biochemical Journal. 2016. Vol. 473. № (10). P. 1379-90. URL: https://doi.org/10.1042/BCJ20160214.

${ }^{62}$ Dynamics of Receptor-Operated Ca2+ Currents through TRPC Channels Controlled via the PI(4,5)P2-PLC Signaling Pathway / Mori M. X. et al. Frontiers in Pharmacology. 2015. Vol. 6. P. 22. URL: https://doi.org/10.3389/fphar.2015.00022.

${ }^{63}$ Identification of a Protein Kinase C-Dependent Phosphorylation Site Involved in Sensitization of TRPV4 Channel / Peng H. et al.Biochemical and Biophysical Research Communications. 2010. Vol. 391. № (4). P. 1721-25. URL: https://doi.org/10.1016/ j.bbrc.2009.12.140.

${ }^{64}$ Montell C. The History of TRP Channels, a Commentary and Reflection.Pflügers Archiv-European Journal of Physiology. 2011. Vol. 61. № (5). P. 499-506. URL: https://doi.org/10.1007/s00424-010-0920-3. 
also may be gated by metabotropic receptors, coupled with several G-protein subtypes ${ }^{65}$.

In uterine smooth muscle cells TRP channels of canonical family (TRPC) are shouwn to be activated by GPCR. In nonpregnant and pregnant uterus TRPC1/4/6 are expessed and have been dmostrated to be involved both in capasitative calciun inflow and in response to oxytocin ${ }^{66}$. TRPC6 have been found to be activated by endogenous peptide 1-oleoyl-2-acetylglycerol (OAG) that demonstrates the ability of these channels to open in response to PKC independently to intracellular calcium changes that usually follow GPCR effects on myometrium ${ }^{67}$.

Ulloa A. et al. have shown a decrease of oxytocin, PGF2a-stimulated elevation of intracellular calcium in PHM1-41 cells and primary human myometrial cells with TRPC4 knockdown by shRNA that proves the role of TRP channels as end points in hormonal regulation of myometrium functioning. At the same time, the calcium inflow induced by store depletion caused by inhibition of SERCA were not affected by TRPC4 knockdown ${ }^{68}$. At the same time we demonstrate in our experiments on isolated myometrium strips from 18-23 day pregnant rats, that SR stores could be involved in the stretch induced stimulation of contraction via calcium induced $\mathrm{Ca}^{2+}$ release (Fig. 1.).

$\mathrm{n}$ rat myometrium muscarinic acetylcholine reseptors also appeared to mediate the signal via TRPC channels. Our data revealed significant deacrease of contractile response of rat pregnant myometrium strips to carbachol $(50 \mathrm{mM})$ under selective antagonist of TRPC4application ${ }^{69}$.

65 Rosasco M. G., GordonS. E. TRP Channels: What Do They Look Like? In: Neurobiology of TRP ChannelsEmir TLR, editor. 2nd edition. Boca Raton (FL): CRC Press/Taylor \& Francis; 2017. Chapter 1. URL: http://www.ncbi.nlm.nih.gov/pubmed/ 29356490.

${ }^{66}$ Expression of Capacitative Calcium TrpC Proteins in Rat Myometrium During Pregnancy / Babich L. G. Biology of Reproduction. 2004. Vol. 70. № (4). P. 919-24. URL: https://doi.org/10.1095/biolreprod.103.023325.

${ }^{67}$ Attenuation of Canonical Transient Receptor Potential-Like Channel 6 Expression Specifically Reduces the Diacylglycerol-Mediated Increase in Intracellular Calcium in Human Myometrial Cells / Chung D. et al. Endocrinology. 2010. Vol. 151. № (1). P. 406416. URL: https://doi.org/10.1210/en.2009-0085.

68 Reduction in TRPC4 Expression Specifically Attenuates G-Protein Coupled Receptor-Stimulated Increases in Intracellular Calcium in Human Myometrial Cells / Ulloa A. et al. Cell Calcium. 2009. Vol. 46. № (1). P. 73-84. URL: https://doi.org/10.1016/j.ceca.2009.05.003.

69 Moroz O., Zholos A. Uterine myocytes: development, structure and function. Advances in Medicine and Biology / Editor L.V. Berhardt, Nova Science Publishers, Inc.., 2019., Vol. 148, P. 27-96. 


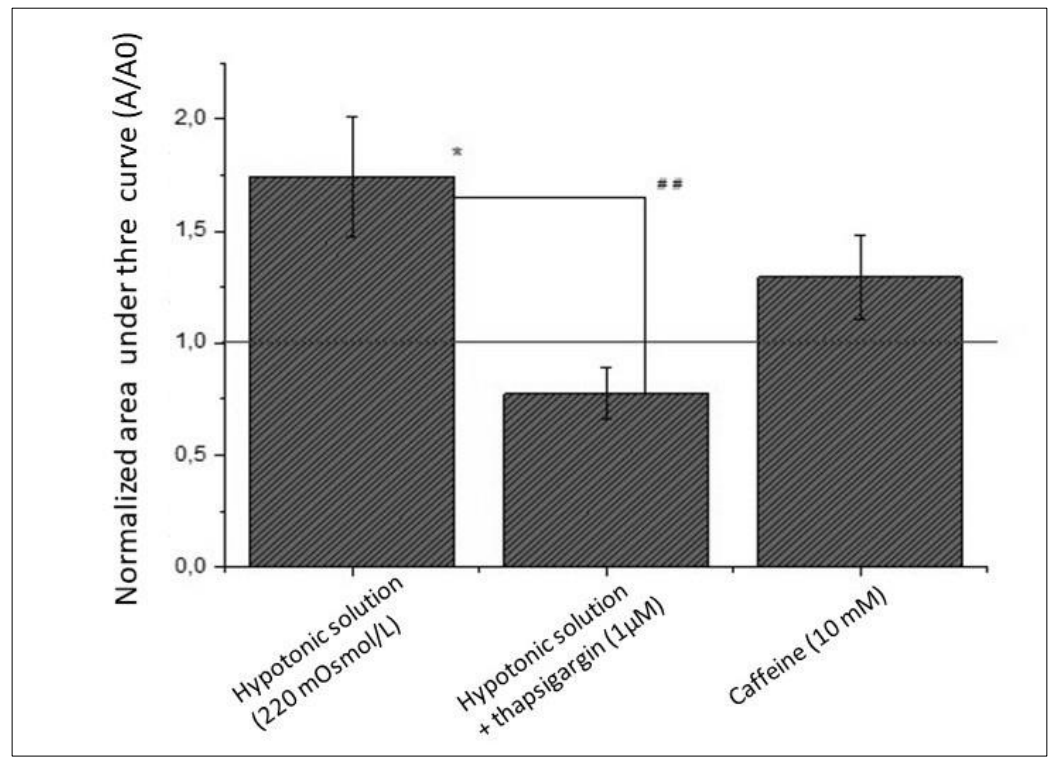

Fig. 1. Application of $1 \mu \mathrm{M}$ of thapsigargin normalize the increased area under the curve of contraction in hypotonic solution $(220 \mathrm{mOsmol} / \mathrm{L})$. Caffeine probe is reformed to demonstrate the capacity of SR store

TRPC4 are also supposed to participate of the stretched induces myocyte response that was proved by electrophysiological and functional studies with lanthanides $\left(1 \mu \mathrm{M} \mathrm{La}^{3+}\right.$ or $\left.\mathrm{Gd}^{3+}\right)$ as agonists and 2-APB as potent TRPC antagonist and stretch applied by $1 \mathrm{~g}$ tension $^{70}$.

ITRPC channels that belong to ligand-gated and can be activated be various endogenous compounds including oxytocin, PIP2, could also be sensitised by citokines and prostaglandins ${ }^{71}$. The other polyunsaturated fatty acids and their derivatives have been demonstrated to modulate TRPV1 functional activity and anionic long chain acylCoA was shown to participate in TRPV1 modulation.This compound that has some similarities with PIP2,

${ }^{70}$ Transient Receptor Potential C4/5 like Channel Is Involved in Stretch-Induced Spontaneous Uterine Contraction of Pregnant Rat / Chung S. et al.Korean Journal of Physiology and Pharmacology.2014. Vol. 18. № (6). P. 503.

${ }^{71}$ Storozhuk M.V, Zholos A.V. TRP Channels as Novel Targets for Endogenous Ligands: Focus on Endocannabinoids and Nociceptive Signalling. Current Neuropharmacology.2018. Vol.16. № (2). P. 137-50. URL: https://doi.org/10.2174/ 1570159X15666170424120802. 
modulate TRPV1 channel activity ${ }^{72}$. Taking into account that the uterus and myometrium in particular express various TRPV channels that are also activated by protons and endogenous lipids ${ }^{73}$, the mechamisms involving dietary lipids could also modulate these channel's finctional role in uterine contraction. Up to date we know that TRPV1 are shown to be involved in pain mechanisms of cervix ripening andin pregnant uterus immunoreactivity to these channels was detected in cervix but not in corpus while in nonpregnant samples TRPV1 were identified in the corpus only ${ }^{74}$.

TRPV4 are another channels expressed in myometrium and besides various physical factors can be stimulated by the derivatives of arachidonic acid (epoxyeicosatrienonic acid (EET) for instance) as endogenous ligands for these channels ${ }^{75}$.Experiments on murine uterine strips demonstrated that TRPV4, when activated, lead to the Ca2+ entry and contraction development and appeared to mediate oxytocin-induced contractile response which is proved by its diminishing under TRPV4 global deletion ${ }^{76}$. Being localized in aveolae (invaginationsof myocyte membrane reach in special proteins and lipids), TRPV4 channels in myometrium are often interacting physically or functionally with other ion channels. Their effect on BKca could result in membrane hyperpolarization or when closely localized with voltage-gated L-type $\mathrm{Ca} 2+$ could trigger their opening and action potential development ${ }^{77}$. TPRV4 channels are described to participate in the stimulating effect of oxytocin and prostaglandin F2 $\alpha$ on the preparations of pregnant women myometrium and on TRPV4 -/- mice that have developed reduce response to

${ }^{72}$ Intracellular Long-Chain Acyl CoAs Activate TRPV1 Channels/ Yu y. et al. PLoS ONE. 2014. Vol. 9. № (5). P.e 96597. URL: https://doi.org/10.1371/journal. pone.0096597.

73 TRPV4: Molecular Conductor of a Diverse Orchestra /White J.P. et al. Physiological Reviews. 2016. Vol. 96. № (3. P. 911-73. URL: https://doi.org/10.1152/ physrev.00016.2015.

${ }^{74}$ Influence of Pregnancy and Labor on the Occurrence of Nerve Fibers Expressing the Capsaicin Receptor TRPV1 in Human Corpus and Cervix Uteri /Tingåker B.K. et al.Reproductive Biology and Endocrinology. 2008. Vol.6. P. 8. URL: https://doi.org/10.1186/1477-7827-6-8.

${ }^{75}$ TRPV4: Molecular Conductor of a Diverse Orchestra / White J.P. et al. Physiological Reviews. 2016. Vol. 96. № 3. P. 911-73. URL: https://doi.org/10.1152/ physrev.00016.2015.

${ }^{76}$ The Transient Receptor Potential Vanilloid 4 Channel Modulates Uterine Tone during Pregnancy / Ying L. et al. Science Translational Medicine. 2015. Vol. 7. № (319). P. 319ra204-319ra204. URL: https://doi.org/10.1126/scitranslmed.aad0376.

77 TRPV4: Molecular Conductor of a Diverse Orchestra / White J.P. et al. Physiological Reviews. 2016. Vol. 96. № 3. P. 911-73. URL: https://doi.org/10.1152/ physrev.00016.2015. 
oxytocin $^{78}$. So up to date we have biased findings about role of TRPV4 in regulation of myometrium which determines the urgent need to continue investigation with the focus on TRPV4 agonists and antagonists as potent pharmacological tools to affect myometrium contraction in clinic.

Uterine smooth muscle cells express ion channels sensitive to calcium concentration. Recent years chloride channels of such type of gating (ANO1) are intensively studied and are suggested to be responsible for anion conductance that is connected with membrane depolarization and some antagonist of these channels are examined as tocolytics due to their ability to attenuate contractions and reduce myocyte excitability ${ }^{79,80}$.

Voltage- and calcium sensitive $\mathrm{K}+$ channels of large conductance are among most aboundant in uterine smooth muscle cells. They are found to provide significant role (if not the main one) in the quiescent state of uterus throught gestation as they provide strong outward current that repolarise myocyte membrane reducing its excitability and attenuating contraction of the cell ${ }^{81}$. Some studies do not prove the leading role of BKca in myomeyrial quiescense but it should be mentioned that these channels have a lot of modulators that could hardly be controlled in experiments ${ }^{82}$. We conducted experimemts on isolated stips taken from pregnant rat myometrium to explore the potential relaxation effect of quercetin - biophlavonoid that could be found in dietary significant quantities in the yellow fruits and veggies (REF). We administered $3 \mathrm{mg} / \mathrm{ml}$ quercetin dissolved in DMSO (Q) to the bath PSS and record spontaneous isometric contraction by force transducers and related software in normal conditions and under perfusion of the tissue with hypotonic PSS $(220 \mathrm{mOsmol} / \mathrm{L})$. We have also examined the effect of quercetin in the same concentration incorporated into phosphatydylcholine liposomes (PCL-Q). It was found that neither Q nor

${ }^{78}$ The Transient Receptor Potential Vanilloid 4 Channel Modulates Uterine Tone during Pregnancy / Ying L. et al. Science Translational Medicine. 2015. Vol. 7. № (319). P. 319ra204-319ra204. URL: https://doi.org/10.1126/scitranslmed.aad0376.

${ }^{79}$ Dunford J.R., BlanksA.M., GallosG. Calcium Activated Chloride Channels and Their Role in the Myometrium. Current Opinion in Physiology.2020. Vol. 13. P. 43-48 https://doi.org/10.1016/j.cophys.2019.09.010.

${ }^{80}$ Functional Comparison of Anoctamin 1 Antagonists on Human Uterine Smooth Muscle Contractility and Excitability / Hyuga S. et al. Journal of Smooth Muscle Research.2018. Vol. 54. № (0). P. 28-42. URL: https://doi.org/10.1540/jsmr.54.28.

${ }^{81}$ LorcaR. A., Prabagaran M., England, S. K. Functional insights into modulation of BKCa channel activity to alter myometrial contractility. Frontiers in physiology. 2014. Vol. 5. P. 289. URL: https://doi.org/10.3389/fphys.2014.00289.

${ }^{82}$ The role of voltage-gated potassium channels in the regulation of mouse uterine contractility / Smith R. C. et al. Reproductive Biology and Endocrinology. 2007. Vol. 5. № (1). P. 41. DOI 10.1186/1477-7827-5-41. 
PCL-Q changed the amplitude of contraction force. The values of normalized peaks amplitude $\left(\mathrm{A} / \mathrm{A}_{0}\right)$ ranged from $1.01(0.91 ; 1.09)$ in case of $\mathrm{Q}$ to $1.13(1.06 ; 1.12)$ in response to PCL-Q $(\mathrm{n}=5-9 ; \mathrm{p}=0.297$ when substances were compared by Mann-Winey test). In case when $\mathrm{Q}$ was administered after paxilline $(10 \mu \mathrm{M})$, a BKca channel antagonist, peak amplitude remained almost unchanged $-0.95(0.8 ; 1.17) ; \mathrm{p}=0.82$, that indicates the specificity of agonist used. Duration of contraction peaks at the half of their maximal amplitude $\left(\mathrm{T}_{1 / 2}\right)$ remained without changes too. One sample Wilcoxon test demonstrated $\mathrm{p}=0.64,0.8$ and 0.79 respectively. So we may conclude that BKca do not participate in the mechanism of spontaneous contractions in rat pregnant myometrium and quercetin cannot affect the amplitude and power of contractility. The last is proved by the unchanged area under the curve in all experiments. Parameters that are dependent on the myocyte excitability - rise and decay tau (the time required for peak curve to rise or decay by $e$ times) and peak-to-peak frequency were supposed to be affected in response to BKca activation. As fig. 2 demonstrates, quercetin itself does not significantly change the velocity of contraction and relaxation progress but in case when BKca firstly were blocked by paxilline decay tau become significantly lower comparatively to control and in comparison to that after Q only $(\mathrm{p}=0.004)$.

Under the effect of both forms of quercetin, peak-to-peak frequency did not show significantly difference comparatively to control $(p=0.78)$ and each other $(\mathrm{p}=0.35)$ and appeared to be significantly reduced in experiments when agonist was applied after BKca blockade (fig. 3).

PCL-Q itself tends to develop more potent effect but in case of spontaneous contractions this difference was not proved statistically. Interestingly, paxilline when added to the bath solution alone provoke significant decrease of contraction frequency $(p=0.03)$ that could be the consequence that BKca supply potassium outflow in the resting state of uterine myocytes and keep their rhythm of contraction.

Our experiments with the perfusion of myometrium strips with hypotonic solution $(220 \mathrm{mOsmol} / \mathrm{L})$ were conducted to check the hypothesis that cell swelling followed by the membrane stretch trigger opening of stretch activated ion channels among with are TRPV4 and C4 channels that becoming a route of calcium entrance can provoke increased contractility and quercetin as agonist of BKca could be beneficial to oppose this unpleasant effect. Amplitude of contraction have increased under hypotonic stress $(\mathrm{Me}=1.14 ; \mathrm{Q} 1=1.62 ; \mathrm{Q} 3=2.70 ; \mathrm{p}=0.008)$, and load developed by muscular strip (area under the curve) tends to be higher $(p=0.06)$. These parameters remained unchanged after PCL-Q administration but dropped dramatically after paxilline administration (median become only $61.4 \%$ of 
the value registered in control, $\mathrm{p}=0.004)$. In hypotonic solution the contractions demonstrated 3.4-fold increase of frequency $(\mathrm{p}=0.032)$ and decay tau (up to $48.5 \% ; \mathrm{p}=0.042$ ) accompanied by only $6 \%$ reduction of the rise tau $(p=0.538)$. PCL-Qin case of hypotonicity induced increase of myometrium functioning develop several effects: reduced contractionfrequency by $70 \%(\mathrm{p}=0.043$; fig. 4); shortened duration of contractions $\left(\mathrm{T}_{1 / 2}\right.$ reached only $70 \%$ of control value; $\mathrm{p}=0.035$ and decreased the decay tauby $31 \%(\mathrm{p}=0.048)$.

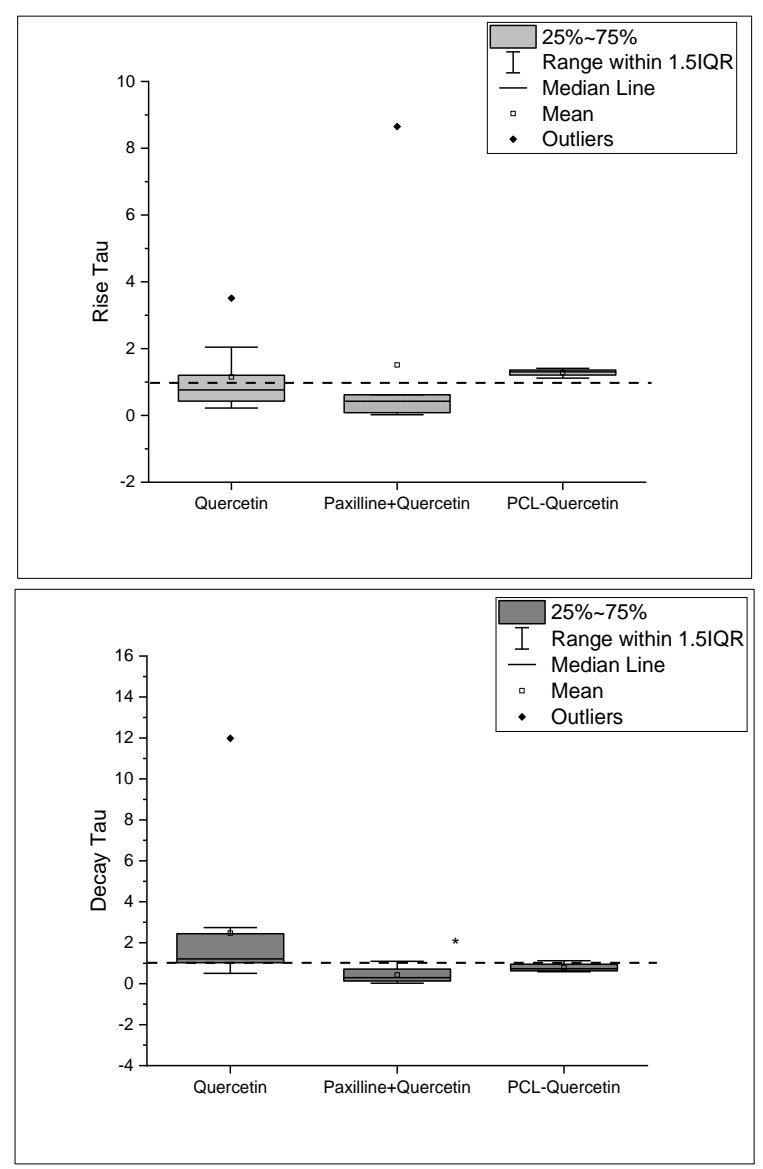

Fig. 2. Effect of different forms of quercetin on normalized kinetic parameters of uterine contractions

$*_{-} \mathrm{p}<0.05$ comparatively to control; $\mathrm{n}=5-10$ 


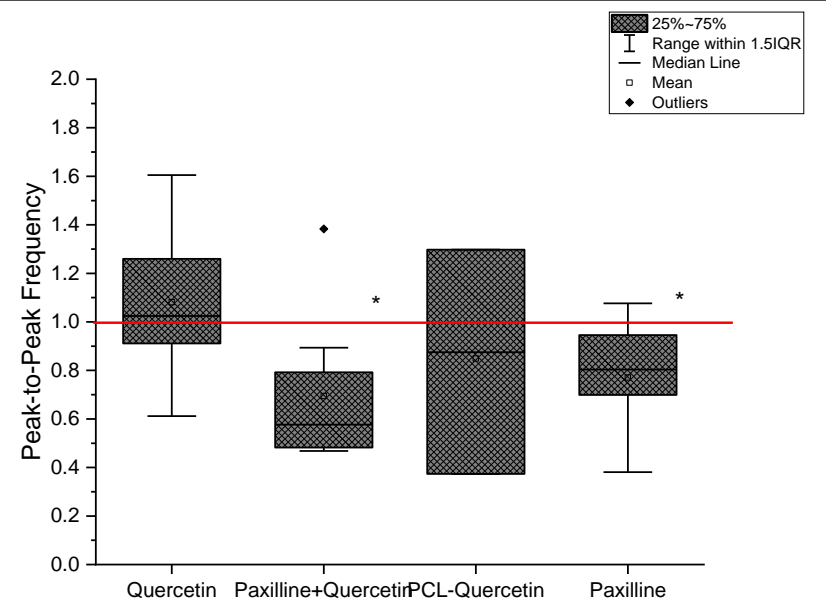

Fig. 3. Changes of the contraction frequency in response to pharmacological modulation of BKca channels

$*-\mathrm{p}<0.05$ comparatively to control; $\mathrm{n}=4-9$

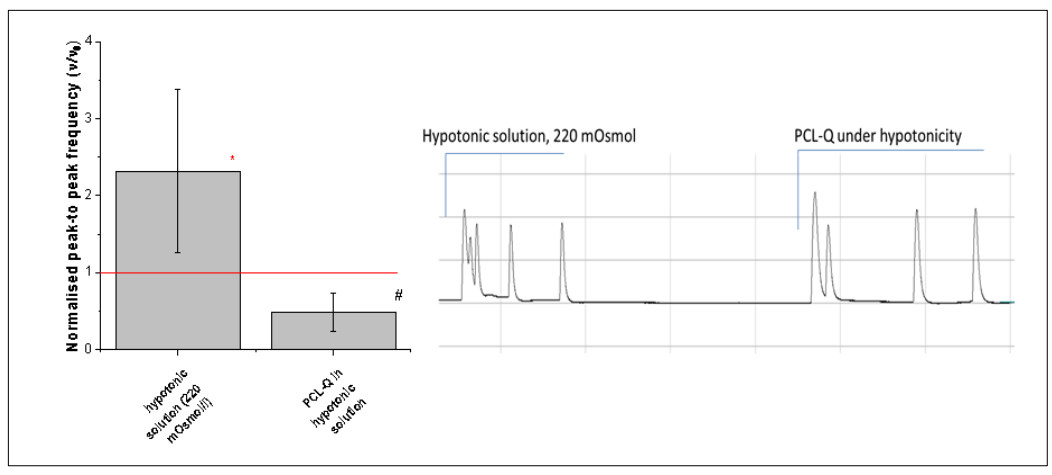

Fig. 4. PCL-Q (100 $\mu \mathrm{g} / \mathrm{ml}$ phospholipid and $3 \mu \mathrm{g} / \mathrm{ml}$ quercetin $)$ effect on contraction frequency under hypotonic stress: $\mathbf{M} \pm \mathbf{m}$;typicalrecord

$\mathrm{n}=5-9 ; *-\mathrm{p}<0.05$ comparatively to control line; $\#-\mathrm{p}<0.05$ comparatively to the valueunder hypotonic conditions

Thus we can conclude that quercetin when incorporated in phosphotydylcholine liposomes could serve as a potent pharmacological agent to reduce the enhanced contractility at least in those cased when it was stimulated by the tissue swallowing under hypotonic stress. 
Mechanism of these beneficial effects underliy in the ability of quercetin to activate BKca channels that we prove in functional studies and the similar was observed in electrophysiological experiments on vascular smooth muscle cells ${ }^{83}$.

Contractions that arise in uterine smooth muscle cells are the consequences of primary plasma membrane depolarization and opening of voltage-gated ion channels among which the crucial role is considered to belong to L-type $\mathrm{Ca}^{2+}$ channels ${ }^{84}$ but $\mathrm{Ca}_{\mathrm{v}} 3.1$ and $\mathrm{Ca}_{\mathrm{v}} 3.2$ subtypes of $\mathrm{T}-\mathrm{Ca}^{2+}$ channels are also expressed ${ }^{85}$. Calcium inflow through these channels via calmodulin/myosin light chain kinase pathway triggers the contractile response. Blockade of these channels is used in clinic to stop preterm contractions and prolong pregnancy.

But there are some other voltage operated channels on myocyte membrane that contribute to the resting level of membrane potential and excitability. Among them are $\mathrm{Na}^{+}$channels that become now considered to play a role in resting membrane potentials $(\mathrm{NaLCN})^{86}$ and also as modulators of actions of other channels that affect membrane permeability to $\mathrm{K}^{+87}$. Voltage-gated $\mathrm{K}^{+}$channels $\left(\mathrm{K}_{\mathrm{v}}\right)$ where shown to be involved in maintaining the resting membrane potential of uterine myocytes and are suggested to be a part of the transition mechanism from gestation to labor as their expression reduced in term-pregnant myometrium ${ }^{88}$.

Besides membrane voltage gated channels uterine myocytes demonstrate anion channels localized on outer mitochondrial membrane and serve to

83. Liposomal Quercetin Potentiates Maxi-K Channel Openings in Smooth Muscles and Restores Its Activity after Oxidative Stress / Melnyk M.I. et al. Journal of Liposome Research. 2018. April. P. 1-8. URL: https://doi.org/10.1080/08982104.2018.1458864.

${ }^{84}$ Young R.C., SmithL. H., McLarenM.D.T-Type and L-Type Calcium Currents in Freshly Dispersed Human Uterine Smooth Muscle Cells. American Journal of Obstetrics and Gynecology. 1993. Vol. 169. № (4). P. 785-792.

${ }^{85}$ Expression of T-type calcium channels ca v 3.1 and ca $v 3.2$ in different segments and different gestational ages of mouse uterus / Zhang, L.J. et al. Int J Clin Exp Med. 2016. Vol. 9. № (2). P. 1375-1381. Available at: www.ijcem.com.

${ }^{86} \mathrm{Na}^{+}$-Leak Channel, Non-Selective (NALCN) Regulates Myometrial Excitability and Facilitates Successful Parturition." Cellular Physiology and Biochemistry/ Reinl E.L. et al. International Journal of Experimental Cellular Physiology, Biochemistry, and Pharmacology. 2018. Vol. 48. № (2). P. 503-515. URL: https://doi.org/ 10.1159/000491805.

${ }^{87}$ Sodium Channels and Transporters in the Myometrium / Amazu C. et al. Current Opinion in Physiology. 2020. Vol. 13. P. 141-144. URL: https://doi.org/10.1016/j.cophys. 2019.11.011.

${ }^{88}$ The role of voltage-gated potassium channels in the regulation of mouse uterine contractility / Smith R. C. et al. Reproductive Biology and Endocrinology. 2007. Vol. 5. № (1). P. 41. DOI 10.1186/1477-7827-5-41. 
create negative potential for accumulation of calcium in these organelles thus maintaining its resting level ${ }^{89}$.

So voltage-operated channels of myocyte membrane and intracellular organelles are involved both in resting activity patterns and in mechanisms of labor.

\section{CONCLUSIONS}

Based on the literature survey and our wn experiments we can summarize that modern experimental and clinical obstetrics have turned to the investigation of the molecular mechanisms at the level of uterine smooth muscle cells and their organelles as potential therapeutictargets for preventing or stimulating of uterine contractility.

Large conductance $\mathrm{Ca}^{2+}$ sensitive ion channels are the perspective targets to affect because they are shown to be activated by biophlavonoids like quercetin, that are rather safe both for mother and fetus and are already introduced into clinic as nutricional supplement. Possibly the only problem remained is to find an appropriate pharmacological form to deliver this substance to the place of action. In this regard liposomes loaded with quercetin, that is poor soludble in water itself, could be promising. Ouer results suggest that in concentration $3 \mathrm{mg} / \mathrm{ml}$ per $100 \mathrm{mg} / \mathrm{ml}$ PCL-Q developes tocolytic effect with the reduction of contraction frequency and duration. Examined in experiments of hypotonic stress that could affect myometrium tissue in cases of preeclampsia, hypertension or diabetes and is characterized with the increase of contraction force and the load produced by the tissue, PCL-Q demonstrates its beneficial effect. Further investigationa we are going to carry to find out if this relaxation could depend on calcium level in myocytes or could be triggerd by the store depletion of some other changes in calcium transport systems.

One more prespective molecular target for developing new drug are TRPC4 and TRPV4 ion channels and the main complication today is to find agonist (or modify existing ones) to overcome their side effect on the central nervous system or to reach the appropriate level of selectivity. When such problems will are solved clinician wil get a powerful tool to stimulate the uterus when it demonstrate insensitivity to oxytocin.

${ }^{89}$ Parkington H.C., Siriwardhana E.R., Coleman H.A..Intracellular Organelles; Key Regulators of Myometrial Activity. Current Opinion in Physiology. 2020. Vol. 13. P. 55-61. URL: https://doi.org/10.1016/j.cophys.2019.10.007. 


\section{SUMMARY}

The article oulines some concepts of understanding the uterine smooth muscle function in regards to the therapies used in clinical obstetrics. Also this researchis aimed to describe ion channels of uterine myocyte as potential molecular targets for the examination and development of new medications that will be promossing in the most common complications of pregnancy and labor - preterm contraction and unsufficient contractility. Experimetns on isolated pregnant rat myometrium strips demonstrated the reduction of contractile power under hypotonic stress after the inhibition of SERCA. Thus, calcium-induced calcium release as the mechanism of increased contractility under such conditionscan be suggested. Quercetin incorporated in liposomes developed more potent tocolytic effect that when dissolved in DMSO. Significant decrease of peak-to-peak frequency and kinetic parameters of contraction have been recorded. Further investigation are required to explore the interactions of these signaling pathways and the role of other proteins that ususally colocalise with BKca channels in caveolae.

\section{REFERENCES}

1. Абрамченко, В.В. Концепция энергетического дефицита и нарушенной функции митохондрий в патогенезе аномалий родовой деятельности. Проблемы репродукиии. 2001. № 4. С. 39-43.

2. Авраменко Т.В., Мощич А.П. Оценка эффективности и безопасности применения препарата Вибуркол для подготовки шейки матки к родам и профилактики аномалий родовой деятельности. Здоровье женщины. 2016. № 7(113). С. 73-78.

3. Айламазян Э.К., Абрамченко В.В. Простагландины в акушерскогинекологической практике. Санкт-Петербург : Петрополис, 1992. 27 с.

4. Арутюнян, Т.Г., Линде В.А., Эльжорукаева Ж.А. Роль кортикотропин-рилизинг гормона в инициации родов. Медицинский вестник юга России. Ростов-на-Дону. 2013. № 4. С. 26-29.

5. Бакшеев Н.С., Орлов Р.С. Сократительная функция матки. Киев : Здоровья, 1986. $184 \mathrm{c.}$

6. Влияние продолжительности родового акта на перинатальные исходы / Железова М.Е. и др. Практическая медицина. 2017. № 7(108) Акушерство. Гинекология. С. 12-17.

7. Дрозд О.О. Порівняльна оцінка ефективності різних методів токолітичної терапії при передчасних пологах : автореф. дис. на здобуття наук. ступеня канд. мед. наук : 14.01.01. Київ, 2006. 20 с. 
8. Дрозд О.О., Орчаков В.О. Сучасний погляд на токолітичну терапію при передчасних пологах. Збірник наукових праџь асоиіаиіï акушерів-гінекологів України. 2015. Вип. 2(36). С. 64-68.

9. Нові клінічні настанови 3 акушерства та гінекології: затв. рішенням Загальних Зборів Членів Громадської організації Київського Міського відділення асоціаціцї акушерів-гінекологів України від 21 грудня 2017 р. № 21/12. / Профессиональные издания, 2019. 266 с.

10. Продолжительность "нормальных" родов в современных условиях. / Баев О.Р. и др. Акушерство и гинекология. 2012. № 1. C. $49-54$.

11. Роль биологически активных молекул в развитии сократительной деятельности матки / Кузьминых Т.У. и др Журнал акушерства и женских болезней. 2019. Т. 68. № 1. С. 21-27.

12. Савицкий Г.А., Савицкий А.Г. Родовая схватка человека: клинико-биомеханические аспекты. Санкт-Петербугр : “ЭЛБИ-СПБ”, 2010. $240 \mathrm{c}$.

13. Сучасні підходи до преіндукції та індукції пологів, засновані на доказах / Вдовиченко Ю.П. та ін. Здоровье женщиныл. 2016. № 3. C. 24-29.

14. Alterations in Gap Junction connexin43/connexin45 Ratio Mediate a Transition from Quiescence to Excitation in a Mathematical Model of the Myometrium / Sheldon R.E. et al. Journal of the Royal Society. 2014. Vol. 11. № (101). URL: https://doi.org/: 10.1098/rsif.2014.0726.

15. Arrowsmith S., Wray S. Oxytocin: Its Mechanism of Action and Receptor Signalling in the Myometrium. Journal of Neuroendocrinology. 2014. Vol. 26. № (6). P. 356-369. URL: https://doi.org/10.1111/jne.12154.

16. Attenuation of Canonical Transient Receptor Potential-Like Channel 6 Expression Specifically Reduces the Diacylglycerol-Mediated Increase in Intracellular Calcium in Human Myometrial Cells / Chung D. et al. Endocrinology. 2010. Vol.151. № (1). P. 406-16. URL: https://doi.org/ 10.1210/en.2009-0085.

17. Blair Bell W. The pituitary body and the therapeutic value of the infundibular extract in shock, uterine atony, and intestinal paresis. Br J Med. 1909. Vol. 2(2553). P. 1609-1613. URL: https://doi.org/10.1136/ bmj.2.2553.1609.

18. Brauer M. M. Smith P.G. Estrogen and Female Reproductive Tract Innervation: Cellular and Molecular Mechanisms of Autonomic Neuroplasticity. Autonomic Neuroscience. 2015. Vol. 187. P. 1-17. URL: https://doi.org/10.1016/j.autneu.2014.11.009.

19. Caldeyro-Barcia R , Alvarez H., Reynolds S. A letter understanding of uterial contractility though simultations recording with internal and seven 
channel external method. Surg. Obstet. Gynaec. 1950. V. 91., № 3. P. 641-652.

20. Central Role for Protein Kinase $\mathrm{C}$ in Oxytocin and Epidermal Growth Factor Stimulated Cyclooxygenase 2 Expression in Human Myometrial Cells / Wouters E. et al. BMC Research Notes. 2014. Vol. 7. № (1). P. 357. URL: https://doi.org/10.1186/1756-0500-7-357.

21. Critical Roles of Gi/o Proteins and Phospholipase C- $\Delta 1$ in the Activation of Receptor-Operated TRPC4 Channels / Thakur D.P. et al. Proceedings of the National Academy of Sciences of the United States of America. 2016. Vol. 113. № (4). P. 109-1097. URL: https://doi.org/10.1073/pnas.1522294113.

22. Dale H.H. On some physiological actions of ergot. J. Physiol. 1906. Vol. 34. № (3). P. 163-206.

23. Dascal N.Ion-Channel Regulation by $G$ Proteins. Trends in Endocrinology and Metabolism. 2001. Vol. 12. № 9. P. 391-398. URL: https://doi.org/10.1016/S1043-2760(01)00475-1.

24. Du Vigneaud V., Resller S., Trippett $S$. The sequence of amino acids in oxytocin, with a proposal for the structure of oxytocin J. Biol. Chem. 1953. Vol. 205(2). P. 949-957.

25. Dunford J.R., Blanks A.M., Gallos G. Calcium Activated Chloride Channels and Their Role in the Myometrium. Current Opinion in Physiology. 2020. Vol. 13. P. 43-48. URL: https://doi.org/10.1016/ j.cophys.2019.09.010.

26. Dynamics of Receptor-Operated $\mathrm{Ca} 2+$ Currents through TRPC Channels Controlled via the PI(4,5)P2-PLC Signaling Pathway / Mori M. X. et al. Frontiers in Pharmacology. 2015. Vol. 6. P. 22. URL: https://doi.org/10.3389/fphar.2015.00022.

27. Effect of Estrogen on Muscarinic Acetylcholine Receptor Expression in Rat Myometrium / AbdallaF. et al. Molecular and Cellular Endocrinology. 2004. Vol. 213. № (2). P. 139-48. URL: https://doi.org/10.1016/j.mce. 2003.10.040.

28. Essential Oil from Lippia Microphylla Cham. Modulates Nitric Oxide Pathway and Calcium Influx to Exert a Tocolytic Effect in Rat Uterus / Silva M. et al. Natural Product Research. 2019. Vol. Jun 5. P. 1-6. URL: https://doi.org/10.1080/14786419.2019.1614578.

29. Estrogen Receptor (ER) Expression and Function in the Pregnant Human Myometrium: Estradiol via ER $\alpha$ Activates ERK1/2 Signaling in Term Myometrium / Welsh T. et al. Journal of Endocrinology. 2012. Vol. 212. № (2). P. 227-38. URL: https://doi.org/10.1530/JOE-11-0358.

30. Expression of Capacitative Calcium TrpC Proteins in Rat Myometrium During Pregnancy / Babich L. G. Biology of Reproduction. 
2004. Vol. 70. № (4). P. 919-24. URL: https://doi.org/10.1095/biolreprod. 103.023325.

31. Expression of T-type calcium channels ca $v 3.1$ and ca $v 3.2$ in different segments and different gestational ages of mouse uterus / Zhang, L. J. et al. Int J Clin Exp Med. 2016. Vol. 9. № (2). P. 1375-1381. Available at: www.ijcem.com.

32. Factors Implicated in the Initiation of Human Parturition in Term and Preterm Labor: A Review / Ravanos K. et al. Gynecological Endocrinology. 2015. Vol. 31 № (9). P. 679-683. URL: https://doi.org/10.3109/09513590. 2015.1076783.

33. Functional Comparison of Anoctamin 1 Antagonists on Human Uterine Smooth Muscle Contractility and Excitability / Hyuga S. et al. Journal of Smooth Muscle Research. 2018. Vol. 54. № (0). P. 28-42. URL: https://doi.org/10.1540/jsmr.54.28.

34. Global, Regional, and National Estimates of Levels of Preterm Birth in 2014: A Systematic Review and Modelling Analysis / Chawanpaiboon S. et al. The Lancet. Global Health. 2019. Vol. 7, № (1) P. 37-46. URL: https://doi.org/10.1016/S2214-109X(18)30451-0.

35. Identification of a Protein Kinase C-Dependent Phosphorylation Site Involved in Sensitization of TRPV4 Channel / Peng H. et al. Biochemical and Biophysical Research Communications. 2010. Vol. 391. № (4). P. 1721-25. URL: https://doi.org/10.1016/j.bbrc.2009.12.140.

36. Ilicic M., Tamas Z., Paul J.W. The Regulation of Uterine Function During Parturition: An Update and Recent Advances. Reproductive Science. 2020. Vol. 27, № (1). P. 3-28. URL: https://doi.org/10.1007/s43032-01900001-y.

37. Influence of Pregnancy and Labor on the Occurrence of Nerve Fibers Expressing the Capsaicin Receptor TRPV1 in Human Corpus and Cervix Uteri / Tingåker B.K. et al. Reproductive Biology and Endocrinology. 2008. Vol. 6. P. 8. URL: https://doi.org/10.1186/1477-7827-6-8.

38. Intracellular Long-Chain Acyl CoAs Activate TRPV1 Channels / Yu y. et al. PLoS ONE. 2014. Vol. 9. № (5). P. 96597. URL: https://doi.org/ 10.1371/journal.pone.0096597.

39. Klimek M. Comparative Analysis of ACTH and Oxytocinase Plasma Concentration during Pregnancy. Neuroendocrinology Letters. 2005. Vol. 26. № (4). P. 337-341. URL: www.nel.edu.

40. Liposomal Quercetin Potentiates Maxi-K Channel Openings in Smooth Muscles and Restores Its Activity after Oxidative Stress / Melnyk M.I. et al. Journal of Liposome Research. 2018. April. P. 1-8. URL: https://doi.org/10.1080/08982104.2018.1458864. 
41. Lorca R. A., Prabagaran M., England, S. K. Functional insights into modulation of $\mathrm{BKCa}$ channel activity to alter myometrial contractility. Frontiers in physiology. 2014. Vol. 5. P. 289. URL: https://doi.org/ 10.3389/fphys.2014.00289.

42. Maternal mortality:веб сайт. URL: https://www.who.int/newsroom/fact-sheets/detail/maternal-mortality.

43. Mederos y Schnitzler M., Gudermann T., Storch U. Emerging Roles of Diacylglycerol-Sensitive TRPC4/5 Channels. Cells. 2018. Vol. 7. № (11). P. 218. URL: https://doi.org/10.3390/cells7110218.

44. Mesiano S. Myometrial Progesterone Responsiveness and the Control of Human Parturition. Journal of the Society for Gynecologic Investigation. 2004. Vol.11. № (4). P. 193-202. URL: https://doi.org/10.1016/ j.jsgi.2003.12.004.

45. Molecular Evidence of Functional Progesterone Withdrawal in Human Myometrium / Nadeem L. et al. Nature Communications. 2016. Vol. 7. № (1). P. 115-165. URL: https://doi.org/10.1038/ncomms11565.

46. Montell C. The History of TRP Channels, a Commentary and Reflection. Pflügers Archiv - European Journal of Physiology. 2011. Vol. 61. № (5). P. 499-506. URL: https://doi.org/10.1007/s00424-010-0920-3.

47. Moroz O., Zholos A. Uterine myocytes: development, structure and function. Advances in Medicine and Biology / Editor L.V. Berhardt, Nova Science Publishers, Inc., 2019. Vol. 148. P. 27-96.

48. Muscarinic Receptor Subtypes Involved in Carbachol-Induced Contraction of Mouse Uterine Smooth Muscle / Kitazawa T. et al. NaunynSchmiedeberg's Archives of Pharmacology. 200. Vol. 377. № (4-6). P. 503-513. URL: https://doi.org/10.1007/s00210-007-0223-1.

49. Myatt L., Lye S. J. Expression, Localization and Function of Prostaglandin Receptors in Myometrium. Prostaglandins Leukotrienes and Essential Fatty Acids. 2004. Vol. 70. № (2). P. 137-148. URL: https://doi.org/10.1016/j.plefa.2003.04.004.

50. Myometrial Mechanoadaptation during Pregnancy: Implications for Smooth Muscle Plasticity and Remodelling / Wu X. et al. Journal of Cellular and Molecular Medicine. 2008. Vol. 12. № (4) P. 1360-1373. URL: https://doi.org/10.1111/j.1582-4934.2008.00306.x.

51. $\mathrm{Na}^{+}$-Leak Channel, Non-Selective (NALCN) Regulates Myometrial Excitability and Facilitates Successful Parturition" Cellular Physiology and Biochemistry / Reinl E.L. et al. International Journal of Experimental Cellular Physiology, Biochemistry, and Pharmacology. 2018.Vol. 48 ; № (2). P. 503-515. URL: https://doi.org/10.1159/000491805.

52. Oxytocin Can Regulate Myometrial Smooth Muscle Excitability by Inhibiting the Na+-activated K+ Channel, Slo2.1 / Ferreira J.J. et al. 
The Journal of Physiology. 2019. Vol. 597. № (1). P. 137-149. URL: https://doi.org/10.1113/JP276806.

53. Parkington H.C., Siriwardhana E.R., Coleman H.A. Intracellular Organelles; Key Regulators of Myometrial Activity. Current Opinion in Physiology. 2020. Vol. 13. P. 55-61. URL: https://doi.org/10.1016/ j.cophys.2019.10.007.

54. Postpartum uterine response to oxytocin and carbetocin / Amsalem $\mathrm{H}$. et al. J Reprod Med. 2014. Vol. 59. № 3-4. P. 167-173.

55. Progress in Understanding Electro-Mechanical Signalling in the Myometrium / Wray S. et al. Acta Physiologica 2015. Vol. 213. № (2). P. 417-431. URL: ttps://doi.org/10.1111/apha.12431.

56. Prophylactic use of ergot alkaloids in the third stage of labour / Liabsuetrakul T. et al. Cochrane Database Syst Rev. 2007. Issue 2: Art No:CD005456.

57. Prostaglandins for prevention of Postpartum haemorrhage / GulmezogluA.M. et al.Cochrane Database Syst Rev. 2004. Issue I: Art. N: CD000494.

58. Reduction in TRPC4 Expression Specifically Attenuates G-Protein Coupled Receptor-Stimulated Increases in Intracellular Calcium in Human Myometrial Cells / Ulloa A. et al. Cell Calcium. 2009. Vol. 46. № (1). P. 73-84. URL: https://doi.org/10.1016/j.ceca.2009.05.003.

59. Regulator of G-Protein Signalling and GoLoco Proteins Suppress TRPC4 Channel Function via Acting at Gai/O / Jeon J.P. et al. Biochemical Journal. 2016. Vol. 473. № (10). P. 1379-90. URL: https://doi.org/ 10.1042/BCJ20160214.

60. Remodeling of Uterine Innervation / Latini C. et al. Cell and Tissue Research. 2008. Vol. 334 № (1) P. 1-6. URL: https://doi.org/10.1007/ s00441-008-0657-x.

61. Retosiban Prevents Stretch-Induced Human Myometrial Contractility and Delays Labor in Cynomolgus Monkeys / Aye I. et al. The Journal of Clinical Endocrinology and Metabolism. 2018.Vol. 103/ № (3). P. 1056-1067. URL: https://doi.org/10.1210/jc.2017-02195.

62. Rosasco M. G., Gordon S. E. TRP Channels: What Do They Look Like? In: Neurobiology of TRP Channels Emir TLR, editor. 2nd edition. Boca Raton (FL): CRC Press/Taylor \& Francis; 2017. Chapter 1. URL: http://www.ncbi.nlm.nih.gov/pubmed/29356490.

63. Sanborn B. M. Hormonal Signaling and Signal Pathway Crosstalk in the Control of Myometrial Calcium Dynamics Seminars in Cell and Developmental Biology. 2007. Vol. 18. № 3. P. 305-331. URL: https://doi.org/10.1016/j.semcdb.2007.05.007. 
64. SebghatiM., Chandraharan E. An Update on the Risk Factors for and Management of Obstetric Haemorrhage. Women's Health. 2017. Vol. 13. № (2). P. 34-40. URL: https://doi.org/10.1177/1745505717716860.

65. Siricilla S., Chisom C.I Herington J.L. Drug Discovery Strategies for the Identification of Novel Regulators of Uterine Contractility. Current Opinion in Physiology. 2019. Vol. 13. P. 71-87. URL: https://doi.org/ 10.1016/j.cophys.2019.10.012.

66. Sivarajasingam S. P., Imami N., Johnson M.R. Myometrial Cytokines and Their Role in the Onset of Labour. The Journal of Endocrinology. 2016. Vol. 231. № (3). P. R101-19. URL: https://doi.org/10.1530/JOE-16-0157.

67. Sodium Channels and Transporters in the Myometrium / Amazu C. et al. Current Opinion in Physiology. 2020. Vol. 13. P. 141-144. URL: https://doi.org/10.1016/j.cophys.2019.11.011.

68. Storozhuk M.V, Zholos A.V. TRP Channels as Novel Targets for Endogenous Ligands: Focus on Endocannabinoids and Nociceptive Signalling. Current Neuropharmacology. 2018. Vol. 16. № (2). P. 137-150. URL: https://doi.org/10.2174/1570159X15666170424120802.

69. Taggart M. J, Morgan K.G. Regulation of the Uterine Contractile Apparatus and Cytoskeleton. Seminars in Cell \& Developmental Biology. 2007. Vol. 18. № (3). P. 296-304. URL: https://doi.org/10.1016/ j.semcdb.2007.05.006.

70. The role of voltage-gated potassium channels in the regulation of mouse uterine contractility / Smith R. C. et al. Reproductive Biology and Endocrinology. 2007. Vol. 5. № (1). P.41. doi: 10.1186/1477-7827-5-41.

71. The Transient Receptor Potential Vanilloid 4 Channel Modulates Uterine Tone during Pregnancy / Ying L. et al. Science Translational Medicine. 2015. Vol. 7. № (319). P. 319ra204-319ra204. URL: https://doi.org/10.1126/scitranslmed.aad0376.

72. Tocolytic Therapy with Fenoterol Induces Selective DownRegulation of $\beta$-Adrenergic Receptors in Human Myometrium/ Engelhardt S. et al. The Journal of Clinical Endocrinology \& Metabolism. 1997. Vol. 82. № (4) P. 1235-1242. URL: https://doi.org/10.1210/jcem.82.4.3885.

73. Transient Receptor Potential C4/5 like Channel Is Involved in Stretch-Induced Spontaneous Uterine Contraction of Pregnant Rat / Chung S. et al. Korean Journal of Physiology and Pharmacology. 2014. Vol. 18. № (6). P. 503-508.

74. TRPV4: Molecular Conductor of a Diverse Orchestra / White J.P. et al. Physiological Reviews. 2016. Vol. 96. № (3). P. 911-973. URL: https://doi.org/10.1152/physrev.00016.2015.

75. Use of Mifepristone to Ripen the Cervix and Induce Labor in Term Pregnancies. / Berkane N. et al. American Journal of Obstetrics and 
Gynecology. 2005. Vol.192 № (1). P. 114-120. URL: https://doi.org/ 10.1016/j.ajog.2004.05.084.

76. Which uterotonic is better to prevent the postpartum hemorrhage? Latest news in terms of clinical efficacy, side effects, and contraindications: a systematic review / Gizzo S. Reprod Sci. 2013. Vol. 20. № 9. P. 1011-1019. URL: https://doi.org/10.1177/1933719112468951.

77. Young R.C., Goloma G. Mechanotransduction in Rat Myometrium: Coordination of Contractions of Electrically and Chemically Isolated Tissues. Reproductive Sciences. 2011. Vol.18. № (1). P. 64-69. URL: https://doi.org/10.1177/1933719110379637.

78. Young R.C., Smith L.H., McLaren M.D. T-Type and L-Type Calcium Currents in Freshly Dispersed Human Uterine Smooth Muscle Cells. American Journal of Obstetrics and Gynecology. 1993. Vol. 169. № (4). P. 785-792

Information about authors: Drozd O. O., Candidate of Medical Sciences, Assistant Professor at the Department of Obstetrics and Gynecology № 2 Bogomolets National Medical University 13, Taras Shevchenko blvd, Kyiv, 01601. Ukraine

Moroz O. F., $\mathrm{PhD}$,

Assistant Lecturer at the Department of Biophysics and Medical Informatics Education-scientific center "Institute of Biology and Medicine" of Taras Shevchenko National University of Kyiv 2, Glushkov Ave., Kyiv, 03022. Ukraine 